\title{
Analysis of Innovative Approaches to Training Business English Talents in Local Colleges
}

\section{Shujuan Liu}

Baicheng Normal University, Baicheng, Jilin, 137000

\author{
Keywords: business English; talents training; education method
}

\begin{abstract}
With the continuous advancement of economic globalization, the demand for business talents with a high level of foreign language and excellent communication skills is increasing. Business English refers to English for special purposes. It is mainly professional English terms, which are the professional terms used in business development communication. In addition to business English skills, business personnel also have higher requirements in other areas, which puts higher requirements on the current business personnel training model. From the current status of business talents and the status quo and problems of business English research, further analysis of business personnel training and business English research is conducted, and relevant suggestions are proposed.
\end{abstract}

\section{Introduction}

The cultivation of vocational English majors in vocational colleges is based on professional orientation, market demand as the prerequisite, and employment as the orientation. Based on the establishment of a professional orientation, we will clarify professional training objectives, integrate professional education into the industry and industrial chain, and cultivate high-skilled composite models with rich business knowledge and skilled business operation skills, and strong English application skills and foreign-related activities. Business English talents. The training model of business English based on industry standards is a "double-certificate" model, which is the convergence and continuity between professional qualification certificates and academic credentials. That is to say, the teaching content of the related majors in higher vocational colleges is in accordance with the requirements of the national professional standards, and the integration of academic education and vocational qualifications training is the unification of academic education and vocational qualification education.

\section{Research Status of Business English Talent Training Mode}

The development of higher vocational education requires the active participation of enterprise entities. Through the establishment of a new school-running system that involves all sectors of the society, including government and enterprises, the zero-distance linkage between schools and enterprises is realized, and the promotion of connotation construction and the innovation of personnel training models are realized. Promote the reform of the combination of work-study and talent-training model and improve the quality of personnel training. However, due to the short history of higher vocational business English majors in our country, various vocational colleges have different views on the talent training model, such as: "2+1" personnel training model, "language foundation + business skills" personnel training model, "three lines In parallel, the talent training model, the "five in one" talent training model, the "language ability + professional knowledge + modern comprehensive quality" talent training model, and so on. This phenomenon reflects the lack of systematic theoretical knowledge of the professional business English majors in the talent training model and does not really understand it. So far, the research and practice of the professional business English major on talent training model is still in the process of exploration. The result is that the business English talent training model is out of touch with the enterprise, the lack of work-study combination, lack of industry standard guidance, and the employment quality of 
graduates is low. The focus of business English training model reform is the practicality, openness, and professionalism of the teaching process [1]. In other words, the talent training model should be based on the current status of talent market demand, development trends of industry companies and professional fields, according to professional characteristics, in-depth social surveys, careful analysis of the status quo of the industry and its development trends, in the full investigation of market demand Based on the research, we will learn about the status quo of the talent structure in the industry, the demand for talents, the requirements for positions on knowledge and student employment, and master changes in the demand for business English professionals due to socio-economic development. Through the specific forms of order cultivation, work-study alternation, task-driven, project-oriented, and internship practice, we will actively construct and nurture teaching modes that are conducive to enhancing students' professional ability, employability, and innovation ability, and form a stable and effective business English training model. And summed up to develop the corresponding teaching results.

\section{Analysis of Business English Talent Training Model}

First of all, the professional background of professional English teachers of various universities is mainly English or economic related majors, or they are based on the double degree of English and Business. The difference in professional background will inevitably lead to the teacher's own emphasis on English in the teaching or emphasis on the two conditions of business. Another important issue is that due to institutional and other constraints, the sources of teachers in various colleges are relatively single, mainly from the universities themselves, and there are very few teachers from enterprises and institutions. The main problem of such teacher composition is that teachers often lack practical experience, teachers' language or business knowledge is weak, but they have weak practical abilities. The lack of experience in the implementation of business activities has led to the emergence of teaching on paper. The Business English program aims to develop application-oriented and compound-type talents who are capable of using English to proficiently engage in business activities. Weakness in teacher resources is a bottleneck in the development of Business English.

Due to the constraints of software and hardware resources, college business English major courses still focus on theoretical teaching, and practice teaching actually accounts for a small proportion, or even if a practical teaching course is set up, the course fails to achieve the desired result due to insufficient teachers or experience. . In addition, the requirements for personnel training in the Business English major require both solid basic English skills as well as basic theoretical knowledge in the business sector, and a strong ability to engage in international business activities and conduct business communications. Then, how to weigh the teaching weights of English and business, theory and practice in the curriculum setting is worth pondering.

The business English teaching model is relatively single, still dominated by traditional teachers, teachers teach English and business knowledge, and students accept passive filling. Since the 1990s, the "student-centered" teaching ideology emphasized by the constructivist learning concept has been accepted by the majority of educators, but the effective way to achieve it is still at an exploratory stage. The Business English major is very practical in itself, and talent cultivation has strong application characteristics. The traditional teacher-led teaching methods can no longer meet the needs of the times and the market, and it is difficult to achieve the established goal of personnel training.

Due to the lack of funds, lack of government and social support, etc., Business English majors currently have a weak foundation for the construction of practical training bases in and outside schools. On the campus side, lack of or lack of relevant laboratories and software, lack of off-campus aspects, lack of internship units, internship content and safety issues, etc., lack institutional guarantees and practical implementation options. Practice is in a form of formality, with little success. Internship training bases are the basis and basis of practical teaching. Perfect in-campus and in-house practice training bases are essential for developing practical teaching, cultivating students' actual combat ability, and improving professional qualities and employment 
competitiveness.

\section{Innovative Ways to Cultivate Business English Talents in Local Colleges}

Analyze the position and employment situation of business English personnel training. It can be seen that business English major should take employment as the goal and cultivate ability as the starting point to construct a reasonable and practical professional curriculum system. To build a reasonable professional curriculum system, we must effectively integrate the curriculum from the content and system. The curriculum should be based on the cultivation of students' comprehensive ability, and should be based on the cultivation of English application ability to cultivate business English operation and communication skills. Focusing on the formation of a professional curriculum system with a clear context, establishing an organic whole with knowledge and skills, maximizing the orderly formation, consolidation, and expansion of students' knowledge and ability, embodying English and business, theory and practice, knowledge and skills Organically combined. In this regard, the business English major curriculum system must establish four major modules: professional foundation, professional core, comprehensive ability, and skills practice. These four modules are independent and closely related to each other, and jointly support their business English professional training goals. According to the new tasks and new situations faced by the 21st century international business English foreign trade exchange, the professional curriculum should be based on English language courses, focusing on practical training in listening, speaking, reading, writing and translating business English. Additional business English courses such as Business English Interpreters, Foreign Trade Correspondence, Foreign Trade Writing, Business English Listening Courses, and Cambridge Business English Test, focusing on teaching Business English. Negotiation skills, Customs practice, and other related practical courses. Expand the practice of teaching, invite university experts or foreign trade personnel with well-known domestic and foreign enterprises to open a series of lectures. Through this series of reforms, students can further increase their understanding of the society, gain rich practical experience, enhance their overall understanding of society, and integrate textbooks and practical activities one step at a time, inspiring students' enthusiasm for participation. It will lay a solid foundation for becoming a trade talent in the future.

The requirements of today's society for university teachers should be those who can comply with the fundamental trend of economic globalization, have international awareness, can engage in international exchanges, can stand at the forefront of international academics, and be courageous to participate in international competition. This requires us to establish a teaching team construction concept that meets the needs of internationalization. This requires us to strengthen the construction of teachers' morality and morality, establish the image of teachers' personality, strive to improve the academic level of teachers, and create a group of teaching masters. This requires us to attach great importance to the cultivation of teachers, ensure that there are planned and step-by-step teacher training, improve the application of modern education technology and information technology for university teachers, and require that we actively absorb the senior management talents and teachers of universities in developed countries. Come to participate in management and teaching. It is one of the effective ways to hire enterprise industry experts to study as a guest professor. Experts can provide detailed and concrete lectures and on-site answers to course content with a deep theoretical level and high technical skill level, so as to improve teachers' academic performance. The level and practical ability; colleges and universities can also hire the company's outstanding talents to become full-time teachers, academic leaders and backbone teachers, teaching and guiding tasks for business English courses. Schools can also plan to send senior management talents and outstanding teachers to universities in developed countries to study, to be visiting scholars, to cooperate in scientific research, to participate in international conferences, etc., to improve academic standards, or to the company's first-line production training, improve practical ability, enhance practice Experience, in order to increase masters training.

At present, colleges and universities are still the main body of personnel training, and colleges and universities fully assume all training responsibilities. In fact, because of the limited resources, 
colleges and universities can hardly completely assume the important task of training talents. One of the important reasons is that the facilities used by universities in practice are insufficient, which restricts the quality of personnel skills training. Business English is a very practical discipline. If there isn't enough practice training, the talents coming out of college will be disconnected from theory and practice, and it is difficult to adapt to the needs of society. To solve this problem, it is necessary to establish an extra-medium training ground, carry out school-enterprise cooperation, etc., increase school-enterprise cooperation, and strengthen contact with the society and local governments, and colleges and universities should form a positive interaction with the society. Local colleges and universities must cooperate with business English-related schools, institutions, companies, etc. to establish student practice training bases in order to cultivate students' familiarity with business English-related business processes in addition to training English language proficiency. Local colleges and universities also hold a number of professional seminars, professional seminars, and various school-enterprise interaction activities to allow students to step out of the campus and integrate into the society, translating their knowledge into practical applications and learning in participation. This will build a broader platform for enhancing students' employability and developing students into high-quality business English talents. School-enterprise cooperation has overcome the problems of setting up business English major courses, the construction of professional courses, and the link between teaching and practice to a certain extent. It also satisfies the need for business English personnel training to adapt to local economic development and talent needs.

\section{Conclusion}

The development of modern society requires application-oriented talents with high business English skills. We must constantly organize and innovate the cultivation of business English professionals, and actively explore and practice new ways of innovating the cultivation model of business English applied talents. Only in this way can we ensure The development of business English with a higher level of quality in running schools and a higher level of talent cultivation can achieve the goal of training business-oriented English majors in applied business, so as to adapt to the ever-evolving needs of the society and the market.

\section{References}

[1] Wang Ying. Research on the Cultivation of Compound Business English Talents[J]. Global Market Information Herald, 2014, (18).

[2] He Xuelian. Study on Business English Talent Cultivation for Regional Economy[J]. Journal of Changchun University, 2012, (4):464-468.

[3] Wang Ying. Problems and Solutions in the Cultivation of Business English Talents in Colleges and Universities [J]. File, 2014, (5): 79.

[4] Wang Youliang, Yu Tingting. A Study of Business English Professional Training Model Based on Demand Analysis [J]. Vocational Education Forum, 2012, (17): 122-124.

[5] Pang Yuan, Xiao Wenping. Research and practice of business English professional training model[J]. Industry and Information Education, 2014, (2): 22-26. 